Jurnal Info Kesehatan

Vol 17, No.1, Juni 2019, pp. 1-15

P-ISSN 0216-504X, E-ISSN 2620-536X

Journal DOI: https://doi.org/10.31965/infokes

Website: http://jurnal.poltekeskupang.ac.id/index.php/infokes

RESEA R C H

Open Access

\title{
Pengaruh Terapi Bekam Kering Terhadap Tekanan Darah Pada Ibu Preeklampsia Postpartum
}

\author{
Yayuk Eliyana \\ Program Studi Magister \\ Kebidanan Fakultas \\ Kedokteran Universitas \\ Brawijaya
}

\author{
Mukhamad Nooryanto \\ Departemen Obgyn RS \\ dr.Saiful Anwar Malang \\ Indonesia
}

Sri Poeranto

\author{
Departemen Fakultas \\ Kedokteran Universitas \\ Brawijaya malang
}

Email: yayukeliyana@uim.ac.id

\begin{abstract}
Abstrak
Preeklampsia selama kehamilan bisa menetap pada masa postpartum dan biasanya akan kembali normal pada minggu pertama postpartum. Angka kejadian preeklampsia atau hipertensi postpartum secara keseluruhan terjadi sekitar $57,1 \%$. Teknik non farmakologis untuk mengatasi hipertensi telah dikembangkan, salah satunya adalah bekam kering sebagai pilihan menurunkan tekanan darah. Penelitian quasy experiment dengan non equivalent control group design. Lokasi penelitian di RSUD Dr. Saiful Anwar Malang. Waktu penelitian dimulai bulan agustus-september 2018. Populasi dalam penelitian ini adalah $34 \mathrm{ibu}$ preeklampsia postpartum dengan kriteria tekanan darah sistolik minimal $140 \mathrm{mmHg}$ dan telah mendapatkan terapi MgSO4 sebelumnya. Sampel penelitian terdiri dari 17 sampel pada kelompok perlakuan dan 17 sampel pada kelompok kontrol. Teknik pengambilan sampel menggunakan consecutive sampling. Variabel independen penelitian ini adalah terapi bekam kering, sedangkan variabel dependen adalah tekanan darah. Uji statistik yang digunakan paired t test dan uji wilcoxon untuk menganalisis perbedaan sebelum dan setelah perlakuan. uji independent sampel t-test dan uji mann whitney untuk menganalisis perbedaan antara kedua kelompok. Hasil uji beda dengan uji wilcoxon didapatkan nilai $p$-value pada tekanan darah sistolik dan diastolik lebih kecil dari taraf signifikansi $\alpha=0,05$, maka dapat disimpulkan bahwa ada perbedaan bermakna tekanan darah ibu preeklampsia postpartum sebelum dan setelah diberikan terapi bekam kering dan terapi standar. Hasil analisis mann whitney diperoleh data bahwa terdapat perbedaan bermakna pada selisih tekanan darah sistolik antara kelompok yang diberi terapi standar dan kelompok yang diberi terapi standar ditambah terapi bekam kering. Berdasarkan hasil penelitian tersebut maka terapi bekam kering bisa digunakan sebagai terapi pendamping untuk menurunkan tekanan darah pada ibu preeklampsia postpartum
\end{abstract}

Kata Kunci: Terapi Bekam Kering, Tekanan Darah, Postpartum, Preeklampsia 


\title{
Effect Of Dry Cupping On Blood Pressure In Preeclampsia Postpartum Mother
}

\begin{abstract}
Preeclampsia during pregnancy can persist in the postpartum period and usually returns to normal in the first week of postpartum. The overall incidence of preeclampsia or postpartum hypertension is around $57.1 \%$. Non-pharmacological techniques to treat hypertension have been developed, one of which is dry cupping as an option to reduce blood pressure. Research on Quasy experiment with non-equivalent control group design. Research location at Dr. Saiful Anwar Malang HOSPITAL. The research time begins in August-September 2018. The population in this study is 34 preeclampsia postpartum mother with systolic blood pressure criteria of at least $140 \mathrm{mmHg}$ and has obtained previous MgSO4 therapy. The research samples consisted of 17 samples on the treatment group and 17 samples in the control group. Sampling techniques using consecutive sampling. The independent variable of this research is dry cupping therapy, while the dependent variable is blood pressure. Test statistics are used paired $\mathrm{T}$ test and Wilcoxon test to analyze the difference before and after treatment. Independent test of the T-Test sample and Mann Whitney test to analyse the difference between the two groups. Different test results with the Wilcoxon test obtained p-value on systolic and diastolic blood pressure smaller than the significance level $\alpha=0.05$, it can be concluded that there were significant differences in postpartum maternal blood pressure with preeclampsia before and after given dry cupping therapy and therapy standard. The results of Mann Whitney's analysis obtained data that there were significant differences in the difference in systolic blood pressure between groups given standard therapy and groups given standard therapy plus dry cupping therapy. Based on the results of these studies, dry cupping therapy can be used as a companion therapy to reduce blood pressure in postpartum mothers with preeclampsia.
\end{abstract}

Keywords: Dry Cupping Therapy, Blood Pressure, Postpartum, Preeclampsia

\footnotetext{
*Correspondence: yayukeliyana@uim.ac.id

Present Address: Malang, Indonesia

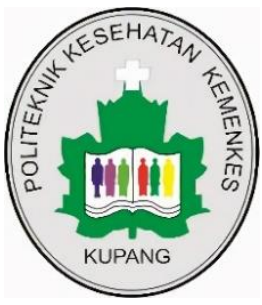

CThe Author(s) 2018. This article is distributed under the terms of the Creative Commons Attribution 4.0 International License (http://creativecommons.org/licenses/by/4.0/), which permits unrestricted use, distribution, and reproduction in any medium, provided you give appropriate credit to the original author(s) and the source, provide a link to the Creative Commons license, and indicate if changes were made. The Creative Commons Public Domain Dedication waiver (http://creativecommons.org/publicdomain/zero/1.0/) applies to the data made available in this article, unless otherwise stated.
} 


\section{PENDAHULUAN}

Preeklampsia merupakan suatu sindroma spesifik yang terjadi pada masa kehamilan ditandai dengan hipertensi dan proteinuria pada pertengahan akhir kehamilan atau di atas 20 minggu kehamilan. Preeklampsia sampai saat ini masih menjadi penyebab terbesar morbiditas dan mortalitas maternal dan neonatal (Warrington et al., 2013; Keman, 2013). Kejadian preeklampsia meningkat seiring dengan semakin tuanya usia kehamilan yang dibuktikan dengan sekitar 0,01/1000 persalinan mengalami preeklampsia ketika kehamilan berusia 20 minggu dan Kejadian preeklampsia saat kehamilan berusia 40 minggu terjadi sekitar 9,62/1000 persalinan.

Laporan terbaru dari World Health Organization (WHO) memperkirakan preeklampsia bertanggung jawab secara langsung atas kematian 70.000 ibu setiap tahunnya di seluruh dunia dan kira-kira 15\% dari semua kematian ibu di Inggris (English et al., 2015). Kejadian preeklampsia meningkat sekitar 30-40\% pada negara-negara berkembang misalnya Indonesia, selain itu di beberapa rumah sakit di Indonesia kejadian perdarahan telah tergeser oleh kejadian preeklampsia sebagai penyebab utama kematian maternal (Fadlun, 2014). Dinas Kesehatan Provinsi Jawa Timur tahun 2013 melaporkan bahwa angka kematian ibu akibat preeklampsia sekitar $36,3 \%$.

Studi sebelumnya menjelaskan bahwa faktor resiko yang meningkatkan kejadian preeklampsia adalah wanita dengan nullipara, riwayat preeklampsia, peningkatan indeks massa tubuh, bertambahnya usia wanita, kehamilan ganda, hipertensi kronis, diabetes melitus serta tekanan psikososial selama kehamilan. Gangguan kejiwaan baik depresi, kecemasan atau keduanya meningkatkan resiko preeklampsia 3,1 kali lipat (Yu et al., 2013). Studi lainnya oleh Qiu et al. (2009) menemukan bahwa suasana hati atau kecemasan pada ibu berkaitan dengan peningkatan resiko 2,12 kali lipat dari preeklampsia.

Perubahan-perubahan fisik yang terjadi pada ibu hamil juga akan mengakibatkan keluhan-keluhan seperti meningkatnya frekuensi buang air kecil dan nyeri punggung. Kondisi tersebut sering kali menyebabkan gangguan tidur pada ibu hamil (Rafknowledge, 2004). Kualitas tidur pada ibu hamil akan berpengaruh pada peningkatan tekanan darah sehingga dapat berpotensi terjadinya preeklampsia. Ibu dengan preeklampsia diharapkan lebih banyak tidur/ istirahat, karena berdasarkan telaah yang didapatkan dari Cochrane, istirahat/ tidur \pm 7 jam dalam sehari dapat menurunkan resiko terjadinya preeklampsia dibandingkan tanpa pembatasan aktivitas (POGI, 2016). 
Preeklampsia selama kehamilan bisa menetap pada masa postpartum dan biasanya akan kembali normal pada minggu pertama postpartum, walaupun masih ada pertentangan tentang masa resolusi wanita dengan preeklampsia postpartum, perbedaan masa resolusi tersebut dapat dipengaruhi oleh tingkat keparahan dari preeklampsia, durasi tindak lanjut, manajemen dan kriteria yang digunakan (Sibai, 2012). Angka kejadian preeklampsia atau hipertensi postpartum secara keseluruhan terjadi sekitar 57,1\%, prevalensi kejadian preeklampsia postpartum di Amerika Serikat yaitu sekitar 18\%. Prevalensi hipertensi postpartum secara de novo berada pada rentang 0,3-27,5\% (Kang et al., 2017). Ibu postpartum dengan preeklampsia akan memerlukan perawatan lebih lama dibandingkan ibu postpartum fisiologis, hal ini menyebabkan resiko terjadinya peningkatan tingkat kecemasan dan kelemahan pada ibu postpartum (Iliadis et al., 2015).

Pencegahan dan pengelolaan hipertensi postpartum yang direkomendasikan saat ini yaitu dengan memberikan antihipertensi pada masa postpartum bila pada saat prenatal sudah diberikan serta memberikan antihipertensi pada wanita dengan preeklampsia berat. Kedua rekomendasi tersebut sampai saat ini cukup kuat untuk tetap menjadi rekomendasi pengelolaan hipertensi pada masa postpartum, walaupun pada kenyataaannya berdasarkan kualitas bukti bisa dikatakan sangat rendah, sehingga diperlukan terapi penunjang untuk mengatasi hipertensi pada ibu postpartum (Pribadi dkk., 2015). Terapi penunjang non farmakologis umumnya relatif dianggap aman sehingga sering digunakan sebagai terapi tambahan pada manajemen standar lainnya (Cassileth, 2007).

Teknik non farmakologis untuk mengatasi hipertensi telah dikembangkan, salah satunya adalah bekam kering sebagai pilihan menurunkan tekanan darah. Terapi bekam kering merupakan salah satu jenis dari tehnik bekam, dimana hanya dilakukan pengkopan saja pada titik-titik bekam yang telah ditentukan sebelumnya tanpa melakukan perlukaan pada kulit. Terapi bekam kering bekerja dengan melenturkan otot-otot terutama pada daerah punggung. Pada saat melepas gelas bekam terjadi peningkatan aliran darah pada kulit (reaksi hyperemia), sehingga terjadi mikrosirkulasi pembuluh darah yang dapat menimbulkan efek relaksasi pada otot yang bias menyebabkan terjadinya penurunan tekanan darah. Berdasarkan penelitian yang dilakukan oleh Pratama dkk. menjelaskan terapi bekam kering bisa menurunkan tekanan darah lansia yang mengalami tekanan darah tinggi. Tekanan darah sistolik turun sekitar 15,60 mmHg, sedangkan tekanan darah diastolik mengalami penurunan sekitar $6,80 \mathrm{mmHg}$. 
Mekanisme kerja bekam kering akan merangsang sekresi opioid endogen yaitu beta endorfin ke pembuluh darah serta cairan otak. Endorfin ini akan bekerja langsung pada susunan saraf pusat dan medula spinalis sebagai neurotransmiter, hal ini akan menyebabkan efek analgesik. Berdasarkan penelitian Subadi (2014), terdapat ekspresi beta endorfin pada tikus setelah dilakukan terapi bekam kering sehingga dapat menurunkan nyeri, namun kadar beta endorfin setelah terapi bekam kering pada manusia belum pernah dilakukan. Peningkatan kadar beta endorfin secara signifikan akan menekan ACTH dan kadar kortisol pada manusia (Taylor et al., 1983).

Berdasarkan uraian diatas, melihat pentingnya terapi bekam dalam proses penyembuhan penyakit serta dari beberapa penelitian sebelumnya belum pernah ada yang meneliti efek terapi bekam kering terhadap ibu preeklampsia postpartum, maka peneliti tertarik melakukan penelitian dengan judul "pengaruh terapi bekam kering terhadap tekanan darah pada ibu preeklampsia postpartum".

\section{METODE PENELITIAN}

Penelitian ini merupakan Jenis penelitian yang digunakan adalah quasy experiment dengan non equivalent control group design yaitu suatu rancangan yang berusaha mengungkapkan hubungan sebab akibat dengan cara melibatkan kelompok perlakuan dan kelompok kontrol dimana dalam memilih kedua kelompok tersebut tidak dikerjakan secara acak (Sugiyono, 2014).

Lokasi penelitian ini dilaksanakan di RSUD Dr. Saiful Anwar Malang. Waktu penelitian dilakukan mulai bulan agustus sampai dengan bulan september 2018 . Populasi dalam penelitian ini adalah 34 ibu preeklampsia postpartum yang terdiri dari 17 kelompok perlakuan dan 17 kelompok kontrol. Pada kedua kelompok dilakukan 2 kali observasi tekanan darah yaitu pada hari ke-3 dan hari ke-4. Tindakan yang diberikan pada kelompok perlakuan yaitu pemberian terapi standar untuk menurunkan tekanan darah disertai pemberian terapi bekam kering, sedangkan pada kelompok kontrol tindakan yang diberikan yaitu pemberian terapi standar untuk menurunkan tekanan darah.

Teknik pengambilan sampel menggunakan consecutive sampling yaitu semua subjek yang memenuhi kriteria inklusi dan kriteria eksklusi akan direkrut hingga besar sampel terpenuhi (Hidayat, 2014). Kriteria inklusi dalam penelitian ini adalah ibu postpartum hari ke-3, ibu telah mendapatkan terapi $\mathrm{MgSO} 4$ dan terapi standart untuk hipertensi, sedangkan kriteria eksklusi dalam penelitian ini adalah ibu dengan hipertensi karena faktor lain dan ibu yang mengalami komplikasi preeclampsia serta ibu yang mengalami 
gangguan jiwa dan sedang menjalani perawatan psikoterapi.

Variabel penelitian ini terdiri dari variabel independen, variabel dependen dan variabel perancu. Variabel independen penelitian ini adalah terapi bekam kering,Variabel dependen dalam penelitian ini adalah tekanan darah, serta variabel perancu dalam penelitian ini adalah kualitas tidur, tingkat kecemasan, onset preeklampsia dan riwayat preeklampsia.

Penelitian ini menggunakan analisis deskriptif untuk menganalisis variabel-variabel yang ada secara deskriptif dengan menggunakan tabel distribusi frekuensi yaitu data karakteristik responden. Analisa bivariat untuk menguji perubahan tekanan darah pada ibu preeklampsia postpartum baik pada kelompok kontrol maupun pada kelompok perlakuan setelah diberikan terapi bekam kering.

Uji beda dilakukan untuk mengetahui perbedaan tekanan darah ibu postpartum dengan preeklampsia sebelum dan sesudah dilakukan terapi bekam kering dengan menggunakan paired t test apabila syarat terpenuhi nilai $p>0,05$. Apabila distribusi data tidak normal, maka dilakukan transformasi data terlebih dahulu dan apabila masih tidak normal maka digunakan uji alternatif yaitu uji wilcoxon.

Uji beda untuk mengetahui perbedaan tekanan darah kelompok kontrol dan kelompok perlakuan dilakukan dengan menggunakan uji independent sampel $t$ test jika data berdistribusi normal, tapi jika tidak memenuhi syarat maka memakai uji non parametrik yaitu uji mann whitney.

\section{HASIL PENELITIAN}

RSUD Dr. Saiful Anwar terletak di jalan raya Jaksa Agung Suprapto No. 2 (seberang depan kantor POLRESTA Malang). RSSA telah memenuhi standar pelayanan rumah sakit yang meliputi: administrasi dan manajemen, pelayanan medis, pelayanan gawat darurat, pelayanan keperawatan, rekam medis, pelayanan farmasi, Keselamatan dan Kesehatan Kerja (K3), pelayanan radiologi, pelayanan laboratorium, pelayanan kamar operasi, pelayanan pengendalian infeksi di rumah sakit, pelayanan perinatal resiko tinggi, pelayanan rehabilitasi medik, pelayanan gizi, pelayanan intensif dan pelayanan darah.

\section{Karakteristik Sampel Penelitian}

Data yang telah dikumpulkan, dianalisis dan dinterpretasikan untuk melihat karakteristik ibu postpartum dengan preeklampsia yang mendapatkan perawatan di rumah sakit Dr. Saiful Anwar Malang. 
Tabel 1karakteristik ibu postpartum dengan preeklampsia

\begin{tabular}{|c|c|c|c|}
\hline Variabel & $\begin{array}{c}\begin{array}{c}\text { Kelompok } \\
\text { Perlakuan } \\
(\mathrm{N}=17)\end{array} \\
\text { frekuensi }\end{array}$ & $\begin{array}{c}\begin{array}{c}\text { Kelompok } \\
\text { kontrol } \\
(\mathrm{N}=17)\end{array} \\
\text { frekuensi }\end{array}$ & p-value \\
\hline Usia & $33,24 \pm 6,3^{a}$ & $29,18 \pm 6,984^{a}$ & $0,085^{\mathrm{b}}$ \\
\hline $\begin{array}{c}\text { Kenaikan berat badan } \\
\text { selama hamil }\end{array}$ & $9,18 \pm 5,615^{a}$ & $12,59 \pm 5,959^{a}$ & $0,065^{c}$ \\
\hline Pekerjaan & & & $0,067^{\mathrm{d}}$ \\
\hline IRT & 15 & 9 & \\
\hline Swasta & 1 & 6 & \\
\hline PNS & 1 & 2 & \\
\hline Pendidikan terakhir & & & $0,161^{\mathrm{d}}$ \\
\hline SD & 4 & 0 & \\
\hline SMP & 6 & 7 & \\
\hline SMA & 6 & 7 & \\
\hline Perguruan TInggi & 1 & 3 & \\
\hline Paritas & & & $0,085^{\mathrm{e}}$ \\
\hline Primi para & 1 & 6 & \\
\hline Multi para & 16 & 11 & \\
\hline Suami ke- & & & $1,000^{\mathrm{e}}$ \\
\hline 1 & 15 & 15 & \\
\hline 2 & 2 & 2 & \\
\hline Riwayat diabetes & & & $0,485^{\mathrm{e}}$ \\
\hline Ada & 0 & 2 & \\
\hline Tidak ada & 17 & 15 & \\
\hline Riwayat preeklampsia & & & $1,000^{\mathrm{e}}$ \\
\hline Ada & 4 & 3 & \\
\hline Tidak ada & 13 & 14 & \\
\hline $\begin{array}{l}\text { Riwayat Keluarga } \\
\text { dengan preeklampsia }\end{array}$ & & & $0,656^{\mathrm{e}}$ \\
\hline Ada & 4 & 2 & \\
\hline Tidak ada & 13 & 15 & \\
\hline Riwayat abortus & & & $1,000^{\mathrm{e}}$ \\
\hline Ada & 3 & 2 & \\
\hline Tidak ada & 14 & 15 & \\
\hline Onset preeklamsia & & & $0,491^{\mathrm{e}}$ \\
\hline$<34$ minggu & 9 & 6 & \\
\hline$\geqslant 34$ minggu & 8 & 11 & \\
\hline Tingkat kecemasan & & & $1,000^{\mathrm{e}}$ \\
\hline Tidak ada kecemasan & 14 & 15 & \\
\hline Kecemasan ringan & 3 & 2 & \\
\hline Kualitas tidur & & & $1,000^{\mathrm{e}}$ \\
\hline Kualitas tidur baik & 5 & 5 & \\
\hline
\end{tabular}


$\frac{\text { Kualitas tidur buruk }}{{ }^{\mathrm{a}} \text { rata-rata } \pm \text { standar deviasi, }{ }^{\mathrm{b}} \text { dari hasil uji Independent sample t test, }{ }^{\mathrm{c} d a r i} \text { hasil }}$ uji mann whitney, dari hasi uji chi-square, edari hasil uji Fisher's exact test

Karakteristik ibu preeklampsia kelompok kontrol. postpartum berdasarkan tabel diatas Karakteristik ibu preeklampsia didapatkan data rerata usia pada postpartum sebagian besar tidak kelompok perlakuan adalah $33,24 \pm 6,3$ mempunyai riwayat diabetes mellitus, dan pada kelompok kontrol didapatkan tidak mempunyai riwayat abortus, tidak rerata usia ibu adalah $29,18 \pm 6,984$. mempunyai riwayat preeklampsia dan Karakteristik kenaikan berat badan ibu tidak memiliki riwayat keluarga dengan selama hamil pada kelompok kontrol preeklampsia baik pada kelompok adalah 12,59 $\pm 5,959$, sedangkan pada kontrol dan kelompok perlakuan. onset kelompok perlakuan rerata kenaikan preeklampsia pada kelompok perlakuan berat badan ibu adalah 9,18 $\pm 5,615$. $\quad$ sekitar 52,94\% adalah < 34 minggu,

Sebaran data responden berkaitan sedangkan pada kelompok kontrol dengan pekerjaan ibu paling banyak sekitar 64,71\% onset preeklampsia adalah sebagai IRT baik pada kelompok terjadi $\geqslant 34$ mingggu.

perlakuan dan kelompok kontrol. Data Tingkat kecemasan ibu postpartum penelitian karakteristik pendidikan berdasarkan hasil rekapitulasi hamilton terakhir ibu pada kelompok perlakuan anciety rating scale(HARS) sebagian besar sebagian besar adalah SMP dan SMA tidak ada kecemasan pada kedua yaitu sekitar 35,29\%, sedangkan pada kelompok dan dari hasil rekapitulasi the kelompok kontrol pendidikan pittburgh sleep quality index (PSQI) pada terakhirnya adalah SMP dan SMA yaitu kelompok kontrol dan perlakuan sekitar 47,06 \%. Paritas ibu sebagian sebagian besar memiliki kualitas tidur besar adalah multipara baik pada yang buruk dalam satu bulan terakhir. kelompok perlakuan maupun pada 
Hasil Uji beda tekanan darah hari ke3 dan hari ke-4 pada ibu postpartum dengan preeklampsia pada kelompok perlakuan.

Tabel 2 Hasil uji beda tekanan darah hari ke-3 dan hari ke-4 pada kelompok perlakuan

\begin{tabular}{cc}
\hline Variabel & $\boldsymbol{p}$-value \\
\hline Tekanan darah sistolik & 0,001 \\
Tekanan darah diastolik & 0,005 \\
\hline
\end{tabular}

Hasil uji beda dengan uji wilcoxon didapatkan nilai $p$-value pada tekanan darah sistolik dan diastolik lebih kecil dari taraf signifikansi $\alpha=0,05$, maka dapat disimpulkan bahwa ada perbedaan bermakna tekanan darah ibu postpartum dengan preeklampsia sebelum dan setelah diberikan terapi bekam kering dan terapi standar.

Hasil Uji beda tekanan darah hari ke3 dan hari ke-4 pada ibu postpartum dengan preeklampsia pada kelompok kontrol.
Tabel 3 Hasil uji beda tekanan darah hari ke-3 dan hari ke-4 pada kelompok kontrol

\begin{tabular}{cc}
\hline Variabel & $\boldsymbol{p}$-value \\
\hline Tekanan darah sistolik & 0,058 \\
Tekanan darah diastolik & 0,791 \\
\hline
\end{tabular}

Uji beda tekanan darah sistolik hari ke-3 dan hari ke-4 pada kelompok kontrol memakai uji wilcoxon karena distribusi data tidak normal. Hasil analisis diperoleh data $p$-value $=0,058>$ nilai $\alpha=0,05$, sehingga dapat ditarik kesimpulan bahwa tidak ada perbedaan bermakna antara tekanan darah sistolik hari ke-3 dan hari ke-4.

Sedangkan untuk uji beda tekanan diastolik antara hari ke-3 dan ke-4 menggunakan uji paired t test. Dari hasil analisis diperoleh data $p$-value $=0,791>$ nilai $\alpha=0,05$, sehingga dapat ditarik kesimpulan bahwa tidak ada perbedaan bermakna antara tekanan darah diastolik hari ke-3 dan hari ke-4.

Hasil uji beda selisih tekanan darah pada kelompok perlakuan dan kelompok kontrol.

Tabel 4 Uji mann whitney untuk selisih tekanan darah ibu postpartum dengan preeklampsia pada kelompok perlakuan dan kelompok kontrol

\begin{tabular}{cccccc}
\hline Tekanan darah & Kelompok & Mean & Median & Standar deviasi & p-value \\
\hline Sistolik & Perlakuan & 150 & 150 & 11,180 & 0,002 \\
& Kontrol & 148,82 & 150 & 9,275 & \\
Diastolik & Perlakuan & 92,94 & 90 & 7,717 & 0,100 \\
& Kontrol & 89,41 & 90 & 11,440 & \\
\hline
\end{tabular}

Berdasarkan hasil analisis mann perbedaan bermakna pada selisih whitney diperoleh data bahwa terdapat tekanan darah sistolik antara kelompok 
yang diberi terapi standar dan kelompok yang diberi terapi standar dan terapi bekam kering, hal ini berdasarkan nilai $p$ value $=0,002$ yang $<$ nilai $\alpha=0,05$, sedangkan pada selisih tekanan darah diastolik menunjukkan tidak ada perbedaan bermakna antara kelompok kontrol dan kelompok perlakuan, karena nilai $p$-value $=0,100>$ nilai $\alpha=0,05$.

Uji pengaruh variabel perancu (onset preeklampsia, tingkat kecemasan, kualitas tidur, riwayat preeklampsia) terhadap tekanan darah.

Tabel 5 uji regresi dummy variabel perancu terhadap selisih tekanan darah

\begin{tabular}{l|c|c}
\hline \multicolumn{1}{c|}{ Variabel } & B & p-value \\
\hline Kualitas tidur & $-0,980$ & 0,792 \\
Tingkat kecemasan & 0,409 & 0,934 \\
Onset preeklampsia & 0,757 & 0,829 \\
Riwayat preeklampsia & $-1,560$ & 0,714 \\
\hline
\end{tabular}

Berdasarkan uji statistik dengan regresi dummy menunjukkan bahwa pengaruh kualitas tidur, tingkat kecemasan, onset preeklampsia serta riwayat preeklampsia secara keseluruhan mempengaruhi selisih tekanan darah sistolik sebesar $29,7 \%$ dan sisanya dipengaruhi oleh faktor lain

Secara parsial variabel independent variabel kualitas tidur tidak mempengaruhi nilai selisih tekanan darah sistolik secara signifikan karena sig 0,792, nilai B -0,989 menunjukkan bahwa setiap peningkatan kualitas tidur maka dapat menurunkan tekanan darah sistolik sebesar 0,989.

Pada variabel tingkat kecemasan menunjukkan bahwa nilai $\mathrm{B}$ sebesar 0,409 menunjukkan bahwa tingkat kecemasan dapat meningkatkan tekanan darah sistolik sebesar 0,409 dan dari nilai sig 0,934 pada variabel tingkat kecemasan menunjukkan bahwa varibel tersebut tidak mempengaruhi selisih tekanan darah sistolik pada ibu preeklampsia postpartum.

Nilai sig 0,829 pada variabel onset preeklampsia dan nilai sig 0,714 pada variabel riwayat preeklampsia menunjukkan bahwa kedua variabel tersebut tidak mempengaruhi selisih tekanan darah secara signifikan. Nilai B 0,757 pada variabel onset preeklampsia menunjukkan bahwa semakin dini onset preeklampsia dapat menaikkan tekanan darah sistolik sebesar 0,757 , sedangkan nilai B $-1,560$ pada varibel riwayat preeklampsia menunjukkkan bahwa semakin seseorang tidak memiliki riwayat preeklampsia maka dapat menurunkan tekanan darah sistolik sebesar 1,560 .

Secara keseluruhan variabel kelompok, onset preeklampsia, riwayat preeklampsia, tingkat kecemasan dan kualitas tidur mempengaruhi selisih 
tekanan darah diastolik sebesar 9,7\% sedangkan sisanya di pengaruhi oleh faktor lain. Nilai sig yang ditunjukkan pada semua variabel memiliki nilai $>\alpha=$ 0,05 sehingga semua variabel tidak signifikan mempengaruhi selisih tekanan darah diastolik pada ibu postpartum dengan preeklampsia.

\section{PEMBAHASAN}

Karakteristik ibu preeklampsia postpartum pada penelitian ini jika dilihat berdasarkan data paritas maka terdapat 27 pasien multipara dan 7 pasien primipara. Resiko kejadian preeklampsia pada primigravida lebih tinggi karena pada primigravida terjadi mekanisme imunologik dalam pembentukan blocking antibody terhadap antigen placenta oleh HLA-G (Human Leukocyte Antigen $G$ ) belum sempurna jika dibandingkan dengan multigravida (Cunningham et al., 2012), namun pada penelitian ini paritas terbanyak adalah multipara dengan faktor resiko lain yang mempengaruhi kejadian preeklampsia misalnya riwayat ibu dengan preeklampsia 7 pasien (25,93\%), kehamilan dengan pernikahan yang ke dua 4 pasien (14,81\%), usia ibu > 35 tahun 12 pasien $(44,44 \%)$.

Kejadian preeklampsia pada multipara bisa terjadi karena ibu memiliki riwayat preeklampsia pada kehamilan atau persalinan sebelumnya. Penelitian sebelumnya menunjukkan bahwa riwayat kehamilan dengan preeklampsia akan meningkatkan kejadian preeklampsia (OR: 8,85) (Kurniawan et al.,).

Faktor resiko preeklampsia bisa terjadi pada ibu multipara dengan suami yang berbeda. Berdasarkan hasil penelitian bahwa kejadian preeklampsia terjadi 3,2\% dari nullipara, 3,0\% dari multipara dengan pasangan yang berbeda dan 1,9\% dari multipara dengan pasangan yang sama (Trupin et al., 1996). Hal ini dihubungkan dengan respon imunologi ibu terhadap antigen janin yang berasal dari sperma ayah. Paparan antigen ayah yang berkepanjangan akan menurunkan resiko terjadinya preeklampsia, namun jika ibu multipara memiliki pasangan baru maka akan meningkatkan resiko preeklampsia sama dengan pada ibu dengan nullipara, karena faktor protektif dari pasangan sebelumnya sudah hilang.

Pada penelitian ini jumlah kejadian preeklampsia pada ibu usia $>35$ tahun adalah sekitar 55,88\%. Resiko preeklampsia dapat terjadi pada ibu yang berusia > 35 tahun karena adanya proses degeneratif yang menyebabkan perubahan secara struktural dan fungsional terjadi pada pembuluh darah perifer yang bertanggung jawab terhadap perubahan tekanan darah (El-Gilany et $a l, 2012)$. Hasil penelitian ini didukung dari penelitian yang dilakukan oleh Denantika dkk. (2015) bahwa ibu hamil yang berusia dalam kategori usia resiko tinggi mempunyai kecendrungan untuk 
menderita preeklampsia daripada ibu yang berusia dalam kriteria usia resiko rendah.

Hasil analisis menunjukkan nilai $p$-value $=0,001<$ nilai $\alpha=0,05$ maka dapat disimpulkan ada perbedaan bermakna tekanan darah sistolik antara sebelum dan sesudah pemberian terapi standar yang diberi tambahan terapi bekam kering. Berdasarkan nilai negative ranks didapatkan sekitar 13 pasien (76,47\%) mengalami penurunan pada tekanan darah sistolik setelah diberikan terapi standar dan ditambah dengan terapi bekam kering.

Pada tekanan darah diastolik juga terdapat perbedaan bermakna antara sebelum dan setelah pemberian terapi standar dan terapi bekam kering pada ibu postpartum dengan preeklampsia hal ini dapat ditunjukkan dari nilai $p$ value $=$ 0,008 yang lebih kecil dari $\alpha=0,05$ dan sekitar $41,18 \%$ ibu postpartum dengan preeklampsia mengalami penurunan tekanan darah diastolik.

Penurunan tekanan darah pada ibu preeklampsia postpartum setelah diberikan terapi standar dan terapi bekam kering bisa disebabkan karena usia ibu. Berdasarkan data usia ibu sekitar 10 pasien berusia diantara 20-35 tahun dengan 7 pasien (70\%) didapatkan mengalami penurunan tekanan darah sistolik setelah dilakukan terapi standar dan terapi bekam kering, sedangkan dari 7 pasien yang berusia lebih dari 35 tahun didapatkan bahwa 4 pasien $(57,14 \%)$ tidak mengalami penurunan tekanan darah sistolik setelah diberikan perlakuan. Berdasarkan penelitian sebelumnya menunjukkan bahwa individu dengan usia lebih muda dan sehat mampu menunjukkan respon aliran yang lebih besar setelah pengobatan bekam. Setelah sesi terapi bekam Volume Regulatory Increase (VRI) meningkat secara signifikan. Terapi bekam mampu memperbaiki perifer mikrosirkulasi pada individu muda (Esquivel et al., 2017).

Berdasarkan hasil analisis statistik dengan mann whitney diperoleh data bahwa ada perbedaan yang bermakna pada selisih tekanan darah sistolik antara kelompok yang beri terapi standar dan kelompok yang diberi terapi standar dan terapi bekam kering. Bekam kering berfungsi untuk menurunkan tekanan darah sehingga responden yang menderita hipertensi kemudian diberi terapi bekam kering, maka tekanan darah responden kembali normal. Penelitian yang dilakukan Anees menjelaskan bahwa dalam kasus tekanan darah tinggi, bekam berperan menurunkan volume darah yang mengalir di pembuluh darah sehingga mengurangi tekanan darah, zat nitrit oksida (NO) berperan dalam vasodilatasi (proses perluasan pembuluh darah) sehingga menyebabkan turunnya tekanan darah.

Berdasarkan uraian diatas maka bekam kering dapat direkomendasikan sebagai salah satu terapi pendamping selain pemberian terapi standart untuk 
membantu menurunkan tekanan darah pada ibu preeklampsia postpartum.

\section{KESIMPULAN}

Penelitian ini menghasilkan beberapa kesimpulan antara lain :

1. Ada beda tekanan darah antara sebelum dan setelah pemberian terapi standar dan ditambah terapi bekam kering pada ibu postpartum dengan preeklampsia

2. Tidak ada beda tekanan darah antara sebelum dan setelah pemberian terapi standar pada ibu postpartum dengan preeklampsia

3. Ada beda selisih tekanan darah sistolik antara kelompok kontrol (pemberian terapi standar) dan kelompok perlakuan (pemberian terapi standar dan bekam kering) pada ibu postpartum dengan preeklampsia.

\section{DAFTAR PUSTAKA}

Cassileth B.R., Deng G.E., Gomez J.E., Johnstone P.A., kumar N. And Vickers A.J., 2007. Complementary Therapies and Integrative Oncology in Lung Cancer, ACCP Evidence based Clinical Practice Guidelines CHEST Journal, 132 (3): pp. 340S$354 \mathrm{~S}$.

Cunningham F.G., Leveno K.J., Bloom S.L., Hauth J.C., Rouse D.J., Spong C.Y., 2012. Obstetri Williams (Williams Obstetrics) Edisi 23 alih bahasa oleh Pendit B.U., dkk., EGC, Jakarta.

Denantika O., Serudji J., Revilla., 2015. Hubungan Status Gravida dan Usia Ibu terhadap Kejadian Preeklampsia di RSUP Dr. M. Djamil Padang tahun 2012-2013. http://jurnal.fk.unand.ac.id.Jurnal Kesehatan Andalas; 4 (1).

English F.A., Kenny L.C., McCarthy F.P., 2015. Risk Factors and Effective Management of Preeclampsia. Dove Press Journal: Integrated Blood Pressure Control 8: 7-12.

Esquivel A.A.A., Warner B.J., Gallegos D.M., Cage S.A., 2017.Effect dry cupping on Vascular Funtion among Young Individuals. International Journal of Health Sciences Vol 5 No 3 pp: 10-15.

Fadlun dan Feryanto A., 2014. Asuhan Kebidanan Patologis, Salemba Medika, Jakarta.

Hidayat A.A., 2014. Metode Penelitian

Kebidanan dan Teknik Analisis Data: Contoh Aplikasi Studi Kasus, Edisi 2., Salemba Medika, Jakarta.

Iliadis S.I., Comasco E., Sylven S., Hellgren C., Poromaa I.S., Skalkidou A., 2015. Prenatal and Postpartum Evening Salivary Cortisol Levels in Association with Peripartum Depressive Symptoms. Plos One: 121.

Kang E., Sugarman R., Ramadan H., Mueller A., Shahul S., Perdigao J.L., 2017. Prevalence, Risk Factors and 
Associated Complications of Postpartum Hypertension in Rural Haiti. Pregnancy Hypertension: An International Journal of Women's Cardiovascular Health 10, 135-142.

Keman K., 2013. Patomekanisme Preeklampsia Terkini Mengungkapkan Teori-teori Terbaru tentang patomekanisme

Preeklampsia dilengkapi dengan deskripsi biomolekuler, Universitas Brawijaya Press, Malang.

Kurniawan K., Cathleen F., Lieana C., Miranda A.V., 2018. Maternal Factors Associated with Preeclampsia among Asian: Systematic Review of Large Cohort Studies. Journal of Asian Medical Students Association 6 (1).

POGI. 2016. Diagnosis dan Tata Laksana Pre-eklampsia. Pedoman Nasional Pelayanan Kedokteran. Jakarta. P: hal 6.

Pratama A.I., Maryana., Rudiatin T.I.E., 2014. Pengaruh Terapi Bekam Kering Terhadap Penurunan Tekanan Darah pada Lansia dengan Hipertensi di Dukuh Singoprana Desa Belor Kecamatan Ngaringan Grobogan Jawa Tengah

Pribadi A., Mose J.C., Anwar A.D., 2015. Kehamilan Resiko Tinggi. CV Sagung Seto, Jakarta.

Qiu C., Williams M.A., Leisenring W.M., Sorensen T.K., Frederick I.O., Dempsey J.C., Luthy D.A., 2003. Family History of Hypertension and Type 2 Diabetes in Relation to
Preeclamsia Risk. The American Heart Association: 408-413.

Rafknowledge. 2004. Insomnia dan Gangguan Tidur Lainnya, Jakarta: PT Elex Media Komputindo.

Sibai B.M., 2012. Etiology and Management of Postpartum Hypertension Preeclamsia. American Journal of Obstetrics \& Gynecology: 470-475.

Subadi I., 2014. Mekanisme Penurunan Nyeri Inflamasi Terapi Bekam Kering dan Bekam Basah. Disertasi di akses melalui http://lib.unair.ac.id pada 8 Mei 2018.

Sugiyono., 2014. Metode Penelitian Pendidikan Pendekatan Kuantitatif, Kualitatif dan $R \& D$, Alfabeta, Bandung.

Taylor T., Dluhy R.G., Williams G.H., 1983. $\beta$-Endorphin Suppresses Adrenocorticotrophin and Cortisol Levels in Nourmal Human Subjects, Journal of Clinical Endocrinology and Metabolism Vol 57 No 3: 592-596.

Trupin L.S., Simon L.P., Eskenazi B., 1996. Change in Paternity: a Risk factor for Preeclampsia in multiparas, JSTOR: 240-244.

Warrington J.P., George E.M., Palei A.C., Spradley F.T. and Granger J.P., 2013. Recent Advances in the Understanding of the Pathophysiology of Preeclamsia. Hypertension Journal of American Heart Association, 62: 666-673. 
Eliyana, Y., Nooryanto, M., \& Poeranto, S. (2019). Pengaruh Terapi Bekam Kering Terhadap Tekanan Darah Pada Ibu Preeklampsia Postpartum. JURNAL INFO KESEHATAN, 17(1), 1-15. https://doi.org/10.31965/infokes.Vol17.Iss1.221

Yu Y., Zhang S., Wang G., Hong X., Mallow E.B., Walker S.O. et al., 2013. The Combined Association of Psychosocial Stres and Chronic
Hypertension with Preeclamsia, American Journal of Obstetrics \& Gynecology 209: 438.e1-438.e12.

Ready to submit your research? Choose INFOKES and benefit from:

- fast, convenient online submission

- $\quad$ thorough peer review by experienced researchers in your field

- rapid publication on acceptance

- support for research data

- Open Access which fosters wider collaboration and increased citations

- maximum visibility for your research

At Health Polytechnic of Kupang, research is always in progress.

Learn more http://jurnal.poltekkekupang.ac.id/index.php/infokes 